\title{
The Cretaceous Tectono-Stratigraphic Complexes of Priamurye (Far East of Russia)
}

\author{
Galina L. Kirillova \\ Institute of Tectonics and Geophysics of the Eastern Branch, Russian Academy of Sciences, Khabarovsk, Russia \\ Email: kirillova@itig.as.khb.ru
}

How to cite this paper: Kirillova, G.L. (2019) The Cretaceous Tectono-Stratigraphic Complexes of Priamurye (Far East of Russia) Open Journal of Geology, 9, 680-683. https://doi.org/10.4236/ojg.2019.910074

Received: August 17, 2019

Accepted: September 22, 2019

Published: September 25, 2019

Copyright $\odot 2019$ by author(s) and Scientific Research Publishing Inc. This work is licensed under the Creative Commons Attribution International License (CC BY 4.0).

http://creativecommons.org/licenses/by/4.0/

\begin{abstract}
Complicated structure of Priamurye is described as series of repeated tectonic plates. Fragments of these plates are presented in the Gorin and Lower Amurian zones. It is typical accretionary complexes. Three main tectono stratigraphic systems can be distinguished: a system of oceanic plate, a system of oceanic plate cover during its approach to the subduction zone (siliceous mudstone), and the overlying terrigenous formations.
\end{abstract}

\section{Keywords}

Tectonic Plates, Cretaceous, Priamurye, Russia

\section{Introduction}

The structure of Priamyrye was described as synclinal and anticlinal structures on previous geological maps, because of lacking the faunal evidence. Since the determination of microfaunas (like radiolarians), the structure of Priamyrye became clear. It consists of a series of small plates, and presents a giant accretionary system at the East Asian continental margin.

\section{Study Area}

Studied area is shown in Figure 1.

\section{Data and Method}

The main Method is geological mapping scale 1:50,000 and 1:200,000.

\section{Results}

East Asian continental margin (EACM) presents a giant accretionary system stretching for $5000 \mathrm{~km}$ and gradually increasing to the east for the last 450 


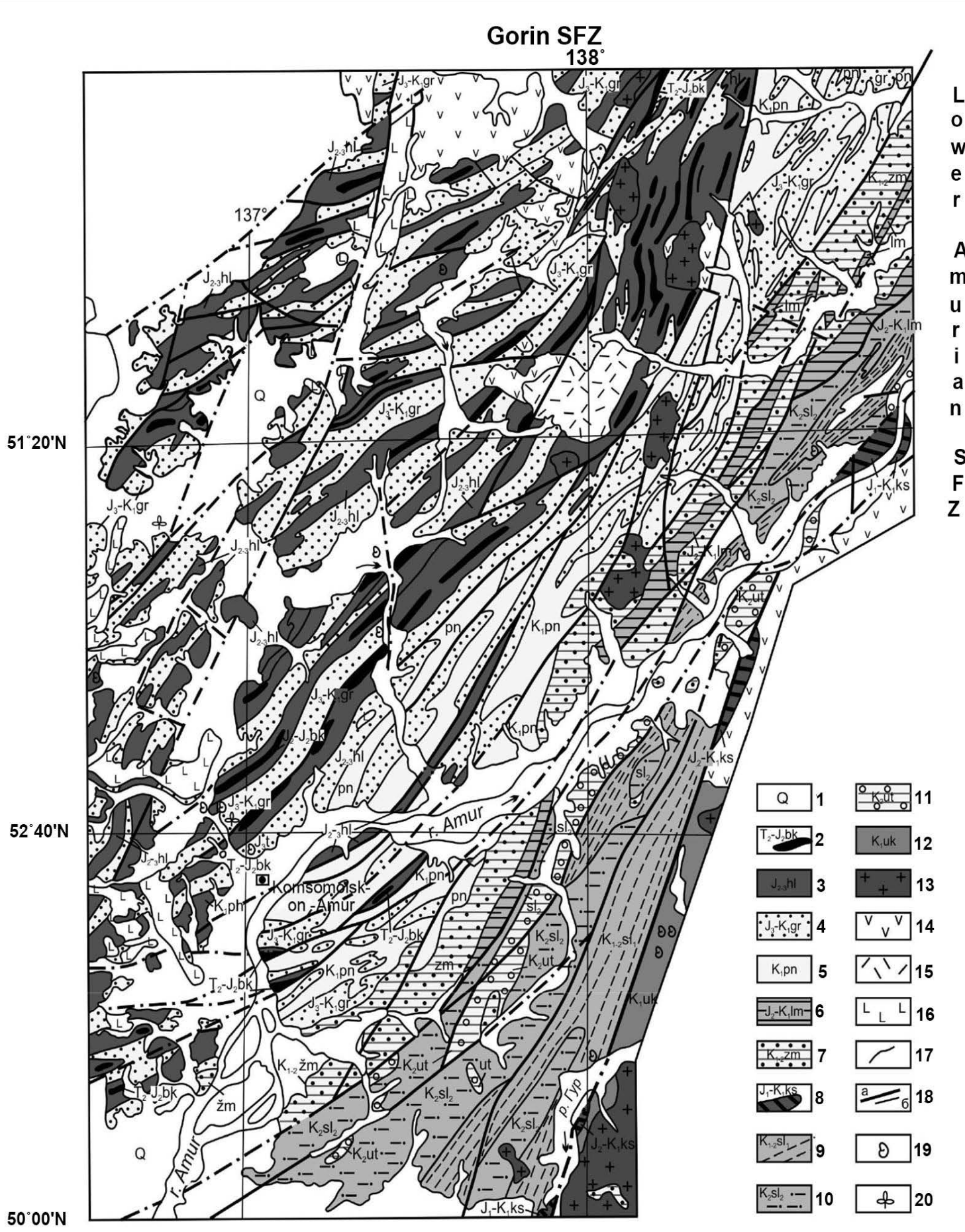

Figure 1. Geologic map of the Amur-Gorin fragment of Late Mesozoicc East Asian margin [1] [2]: Gorin SFZ and Lower Amurian SFZ (Limuri and Chayatyn SFSZ). 1, Quaternary deposits. 2, Boktor unit. 3, Kholvasi unit. 4, Gorin Formation. 5, Pioneer Formation. 6, Limuri unit. 7, Zhormin unit. 8, Kiselevka Formation. 9, Lower Silasinsky subformation. 10, Upper Silasinsky subformation. 11, Utitsky Formation. 12, Uktur Formation. 13 - 15, Upper Cretaceous: 13, Granitoids; 14, Medium volcanites; 15, Acid volcanites. 16, Neogene-Quaternary basalts. 17, Stratone boundary. 18, Faults: a) Major, b) Subordinate. 19. Faunal foundings. 20, Floral foundings. 


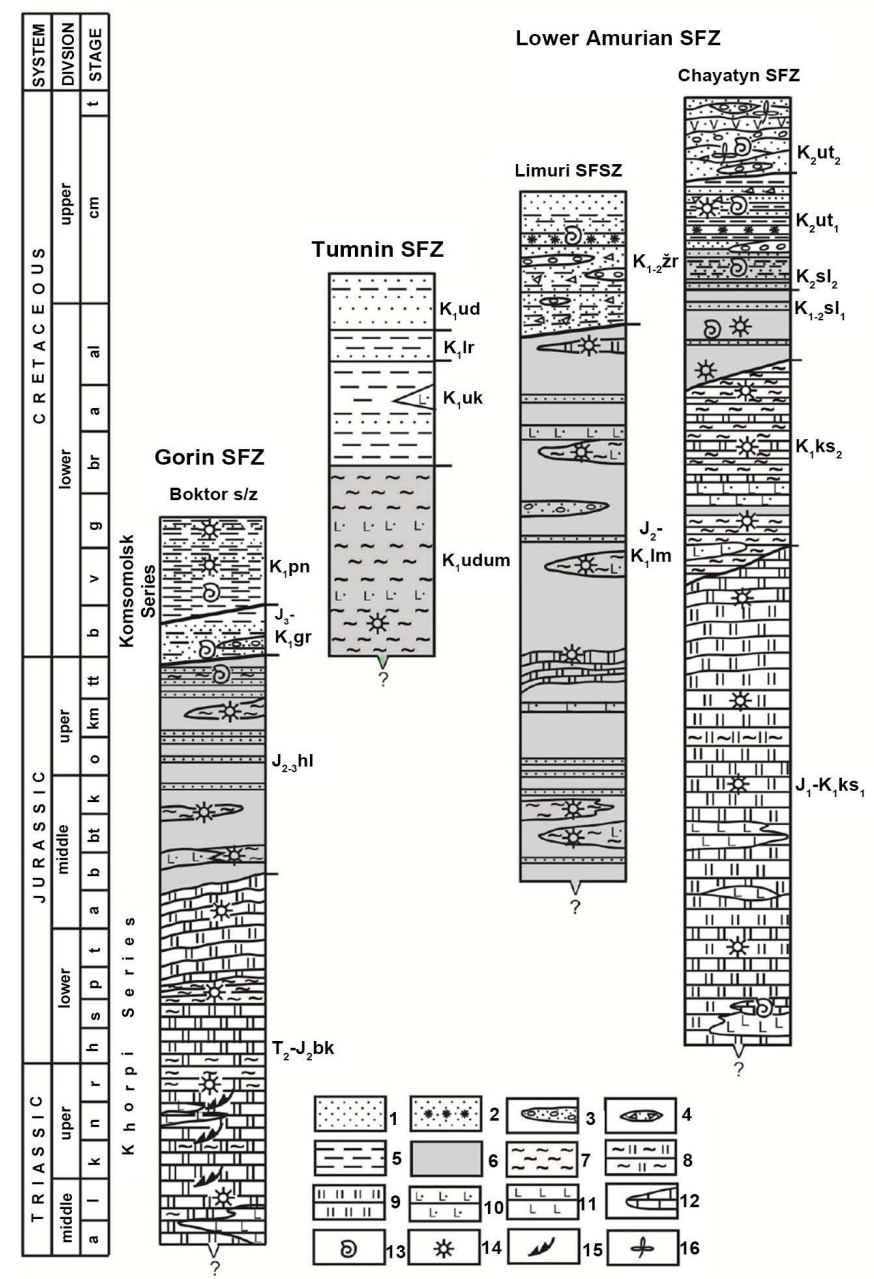

Figure 2. Zonal correlation scheme of lithostratigraphic units. 1, Sandstones. 2, Tufaceous sandstones. 3, Conglomerates. 4, Sedimentation breccia. 5, Siltstones. 6, Clayey shales and aleuropelites. 7, Siliceous-clayey shales. 8, Clayey cherts. 9, Jasper and cherts. 10, Tuff and basic hyaloclastites. 11, Basic lavas. 12, Limestones. 13, Bivalves. 14, Radiolarian. 15, Conodonts. 16, Flora.

million years by accretionary complexes. In Mesozoic, within the boundaries of EACM 6 main periods of accretion are established: $\mathrm{T}_{2} ; \mathrm{J}_{1} ; \mathrm{J}_{2} ; \mathrm{J}_{3} ; \mathrm{J}_{3}-\mathrm{K}_{1}$ and $\mathrm{K}_{1}^{2}$, that were previously discussed in general terms. Accretionary complexes are divided into belts or zones (SFZ) as shown in Figure 1.

In Priamurye, three main tectono-stratigraphic systems can be distinguished: a system of oceanic plate, composed of laminar chert, rare volcanites, a system of oceanic plate cover during its approach to the subduction zone (siliceous mudstone), and the overlying terrigenous formations. Fragments of these systems are presented as shown in Figure 2.

\section{Acknowledgements}

This work was fulfilled supported by the project of the Russian Foundation for 
Basic Research (No. 19-05-000 97/19) and in part by the State task for Y.A. Kosygin of the Institute of Tectonics and Geophysics of the Far Eastern Branch, Russian Academy of Sciences. This is a contribution to UNESCO-IUGS IGCP Project 679.

\section{Conflicts of Interest}

The author declares no conflicts of interest regarding the publication of this paper.

\section{References}

[1] Anoikin, V.I., Kirillova, G.L. and Eikhwald, L.P. (2007) New Notions about Composition, Structure, and Age of the Lower Amurian Fragment of the Late Jurassic to Early Cretaceous Accretionary Prism, Far East. Journal Tikhookeanskaya Geology, 26, 60-77. (In Russian with English abstract)

[2] Kirillova, G.L. and Anoikin, V.I. (2011) Structure of the Amur-Gorin Fragment of the Lower Mesozoic East Asian Accretionary System. Doklady Earth Sciences, 436, 1-5. https://doi.org/10.1134/S1028334X1090112X 